\title{
Explaining Political Agitators: Socialization and Class in the Making of Gani Fawehinmi and Fela Anikulapo Kuti of Nigeria
}

\author{
Olukayode Segun Eesuola \\ *http://dx.doi.org// 0.43 I4/ujah.vI7i3.I
}

\begin{abstract}
Why do certain individuals make everyone's business their business? Why do they get so emotionally involved in public policies as if only they are affected, damning whatever unpleasant consequences their action and inaction may cause? Why do such people neither wait to be mobilized, nor themselves wait to mobilize others before taking antagonistic stands on public issues? Subjecting the lives and times of two prominent Nigerian agitators, Gani and Fela to theoretical interrogations through the life history approach, this paper argues that two basic factors: socialization and class, are major determinants of the attitudes of man towards political issues around him, and that so long as the two factors endure in social formations, individuals will always emerge as different political personalities with different political dispositions. What nations and policy makers do with views and thoughts of agitators towards public good is what needs further debate.
\end{abstract}

\section{Introduction}

The behavioral revolution is a major turnaround in political science. It introduces radical methodological re-orientations, promotes inter-subjectivity, and "identifies the behaviour of individuals or group of individuals as the primary unit of analysis" (Eldersveld \&Katz 2007) in the study of politics. This is why political behaviour is typically "concerned with individual behaviour in the society" (Rose 2003). Without 
focusing on individuals, Dalton and Alix declare, "we cannot systematically explain what citizens actually believe and how they act" (pp. vii). Human attitudes towards politics come in different dimensions, and one critical aspect of it is agitation, or, as interchangeably used in this paper, protest. Protest and agitation keep increasing all over the world, and individuals, rather than groups are playing key roles in them. In 2010 Tunisia, the self immolation protest of Benzoazi sparked off a new era in the political history of North Africa and the Middle East. The uprising that occurred in Egypt and Libya were also linked to the agitation of two individuals: Abdou Hamandah and Afiz Gboha respectively. Before these recent agitations the world had witnessed many prominent ones from individuals such as Mahatma Gandhi, Nelson Mandela and Martin Luther King Junior. Going by Dalton and Alix's foregoing assertion that without focusing on individuals we cannot systematically explain what citizens actually believe and how they act, therefore, it is quite necessary for the behavioral scientist to ask who and what kind of individuals political agitators are.

The political agitator is a unique political animal. Defined from administrative standpoint, he is one who "exaggerates the difference between one rather desirable social policy and another (Policy Science Centre 2). Socially, he is a man of peculiar behavioral composition, his personality having been formed through an interplay of social factors that make him the type that bothers to take emotional extra look and pay critical attention towards public policies and practices that others are often silent about. Family socialization, in terms of the orientation to which people are directly or indirectly exposed in the process of growing up, is the first key psycho- social issue that shapes the political personality, attitudes and perspectives of these individuals. The social class to which they belong is the 
second prominent one. Put together, these three major factors formed the personalities of the two prominent political agitators under study: Gani Fawehinmi (a lawyer, 1938-20 I0), and Fela Anikulapo Kuti (a musician, 1938-1997).

Gani and Fela were born in the same year. They lived around the same period, and under same socio-political circumstances and situations: the corrupt and anti citizens' policies of the military interregnum in Nigeria, especially between 1964 and 1999. While Gani Fawehinmi agitated and protested against a sizeable number of public policies using several rallies and lawsuits, Fela Anikulapo Kuti used his Afrobeat popular music and certain counter cultural activities to venomously criticize and condemn actions and inactions of governments in Nigeria and other parts of the world, 'today, the history of Nigerian politics, especially anti military agitation and quest for egalitarianism cannot be deemed to be complete without the mention of these two agitators. Their agitations and protest attitudes are what this paper intends to explain through socialization and class.

\section{The Making of Political Agitators}

Political agitation is a form of political protest, resistance and contentious behaviour. The political agitator is often fundamentally disenchanted with certain actions or inactions of the political class, and he seeks redress to them in means acceptable to him. The agitator's "protest action threatens elites, and protesters refuse to acknowledge hierarchies and power structures that have been established or established themselves" (Olafsson 433), so, when the political elite make policies in the state, they use the instrumentality of the state to enforce and defend them from anyone who dares raises objection, brandishing punishments, injuries, jail terms and even death to enforce their threat. The political agitator often ignores these consequences, and, most 
times, goes ahead on collision course with the state and its repressive instrumentalities. The following analogy is interesting:

The agitator has come by his name honestly, for he is enough agitated about public policy to communicate his excitement to those about him. He idealizes the magnitude of the desirable social changes which are capable of being produced by a specific line of social action. So, from the standpoint of administrative mind, we might say the agitator is one who exaggerates the difference between one rather desirable policy and another, much as the lover, according to Shaw, exaggerates the difference between one woman and the other " (Public Policy Centre 2-3).

In this paper we perceive agitation and protest as synonymous, and we shall so use them to mean a form of behaviour that are acquired by man over a period of time and that are exhibited in response to certain developments in his political environment. The logic is that an agitator is always an agitator, and he will always agitate for as long as he lives in a political environment because there will always be issues to protest against. How then is this behavior formed, and how are agitators made? Scholars such as Garr (1970), Davies (1962) and Obeschall (1973) have traced rebellious behaviour generally to deprivation, claiming that man develops relative expectations he wants the political system to meet, and that if these expectations are not met, man becomes deprived and subsequently gets frustrated. This frustration soon produces aggression which in turn snowballs to political protest, 
agitation, resistance, rebellion, and all sorts of contentious behaviour '(Olafsson, pp. 433). Also, some Neo Marxists, such as Ralph Milliard, Nico Polanzas, and especially O'Connor (Olson) have argued to successfully develop what in literature is known as legitimacy- stability thesis, which claims that man protests against a polity if he lacks confidence in the political regime, with little regards to whether or not he is deprived. Put directly, the legitimacy-stability school claims that "people translate their dissatisfaction for regimes into protesting against that regime"( O'Connor). Thus, in variance from the deprivation thesis, the position of the legitimacy stability is that people can therefore agitate or protest against a political system or its policies on personal and emotional grounds, political rivalry or ideological differences.

Useem and Useem also criticized the position of the legitimacy-stability theorists, but rather than develop alternative paradigm, they ended with what is best described as 'modified' form of the same thesis, where they claimed that legitimacy crisis was not, on its own, capable of generating political agitation except there was "organized movement that can articulate grievances against the regime and translate it into effective, concrete, strategic programs" (pP. 84I). To Useem and Useem therefore, political agitators must be disillusioned about a political regime, and there must be a social organization that will serve as vehicle of transferring their hatred into protest. These are the preconditions of political protest and agitation. In another light, prominent political scientists: Verba, Kay and Henry (1995), Putman (2000) Dalton (2002), Dalton and Alix Vein (2004), as well as sociologists: Lurched and David (198I) and McAdam (1986) have attempted to explain the nature and characters of political agitators. Their dual disciplinary position highlights three explanatory frameworks: "biological availability, political 
engagement and structural availability" (Cited in Schussman and Soule 1084).

These scholars claim that whether or not an individual will become an agitator or partake in protest action depends, first, on his biographical availability, that is, "personal constraints that may increase the cost and risk of participation: full time employment, marriage and family responsibilities" (Mc Adam, cited in Schussman and Soule 1097).

They also claim that political interest and political knowledge-what they call political engagement- as well as the presence of interpersonal networks with protesters which they tag structural availability, or, in the words of Passy (200I), micro structural account; are principal determinants of political agitation and its participation. Schussman and Soule however argued, after critical exploration and analysis of data used in testing the hypotheses of the combined sociologist and political scientists as indicated by Dalton, et al above, that younger people, not necessarily married or single, were more likely to participate in protest irrespective of their biographical availability. They also assert that people are likely to protest because they are asked to do so" (1097), a position corroborating that of Me Adam, Arrow and Tally (5I), that "contentious political activities such as protest must be understood as developing through social interaction".

Herring also attempted to explain why men protest in the polity. Explaining political protest and agitation from the angle of political alienation, and examining how two theoretical postulations: the mass society theory and the deprivation theory "point to variables which purportedly condition the various modes of political expression," Herring observed that "those who are untrusting and who feel underemployed are significantly more likely to be involved as protesters" (Pp. 135). 


\section{The Role of Socialization}

In its simplest form, "political socialization refers to the ways in which a society transmits its political orientation knowledge, attitudes, norms and values- form generation to generation (Easton 59). The family is the principal agent here, political or otherwise. In fact, Jennies asserts that "from the early scholarly inquiries on through to the present time, the role of the family as a prime agent of socialization has occupied an import in the literature (38). This is because the family is a relatively small yet enduring institution that makes the processes of learning and imitation easy and enduring since it is often the reference point of individuals. Apart from this, the family is the first point of call of the individual, and, to that extent, it determines a lot about individual's behaviour; including the political.

The family as an agent of socialization provides an individual with what Bandera (1973) calls social learning, an informal and untaught form of orientation and education that an individual member of a family, who is born as tabula rasa, acquires through trial and errors, imitation, primary reinforcement, secondary reinforcement and reciprocal determinism. Suffix to say therefore, that people who grow up in families where agitation, protest and activism of some sort prevail, are likely to grow up as agitators, though they may convert their own agitation into other aspects of life. Beyond the scope of the family, socialization extends to the peer group people interact with and the nature of the environment in which they interact. The nature of the entire political environment in which a man is socialized, called ' political opportunity structures' by Eisinger has an impact on political behaviour" (pp.1263). It generally determines whether or not an individual will be disposed to agitation and protest in the first place, the class and stratification of people that will be agitators as well as the forms and dimensions 
their agitations may take. It also addresses the type of reaction that the political system gives to political protest. Explaining the Political Opportunity Structure, Eisinger further declares that:

Such factors as the nature of the chief executive, the mode of elections, the distribution of social skills and status and the degree of social stratification, taken individually or collectively, serve in various ways to obstruct or facilitate citizens' activities in pursuance of their political goals. Other environmental factors such as the climate of governmental responsiveness and the level of community resources help to establish the chances of success of citizen's political activities. In short, elements in the environment impose certain constraints on political activities or open avenue for it. The manner in which individual or group in a political system behaves, then, is not simply a function of resources they command, but of the opinions, weak spots, barrier and resources of the political system itself. There is, in this sense, interaction or linkage between the environment, understood in terms of the notion of a structure of political opportunities, and political behaviour (PP. II-I2).

The unmistakable declaration in the foregoing explanation is that political protest and agitation is largely linked with the nature and character of socialization, first from the family where the life and personality of an individual begin, then down to the wider political environment in which 
a man's socialization continues. A political agitator is often a product of these factors.

\section{The Class Factor}

Apart from socialization, the social class to which a person belongs also plays a very important role in the political attitude the person exhibits. This belief has its root in the Marxian tradition which claims that it is not the being that determines the consciousness but the consciousness that determines the being. This Marxian thesis is a micro-macro analysis that links the political behaviour of man to an amalgam of his socio economic condition and his consciousness. This is why Peterson asserts that "a person thinks politically, what he is, socially", and that "Social characteristics determine political preferences" (Peterson 1990). The observation that "socio economic circumstances always constrain members of various classes to relate differentially to the social structure" (Labinjoh 1982:122), and that such has "implications for individual dramaturgical skills and therefore for the individual's perception of social reality" is another dimension to how social class affect political perception and behaviour. Auvinen believes that the middle class are likely to engage in protest and agitation because they often are the immediate victims of harsh socio economic conditions in the city. This is against the position that middle class would often have conquered hunger and will have enough time and suitable environment to raise further questions about life and society as Labinjoh proposed.

The individuals who come from the middle class are quite often not overwhelmed with material deprivation. They have relative comfort that they need most of the time, and are exposed to materials and people that may influence them to think and ask questions about people and policies around them. This suggests why it is declared that unlike the working 
and under class that are often overwhelmed with scarcity of material values, the middle class often interprets social structures and "soon develop a theory of it" (Ford et al, cited in Labinjoh 1982:6).

\section{Observed Lacuna}

But all the foregoing positions on political agitation and protest have merely explained them as spontaneous actions of people who merely react to certain socio- political circumstances in their environments, not a kind of habit or behaviour that has been systematically internalized, developed and inculcated, over a period of time, before it is exhibited. The closest attempt is the Neo Marxian postulation in the legitimacy-stability school that people translate their dissatisfaction for regimes into protesting against that regime. Outside this, no specific attempts have been made to examine why certain individuals seem to be 'genetically' disposed to protesting and agitating, yet, behavioral approach to the study of politics as earlier asserted through the positions scholars like Eldersveld and Katz as well as Rose. This is why Labinjoh laments that "most theories that came to dominate sociological thinkingstructural functionalism and Marxism-to the extent that they are holistic in approach, neglect the lives of individuals as they are lived day to day, moment by moment; the individual's affect, desires and frustrations (pp. 120), yet, as Dalton and Alix argue, we cannot systematically study human beings.

Freeman (1999) also observes that scholars of political protest and social movements have not been very intense on the aspect of the immediate catalyst, what he calls "spark of life" of protest, and that the 'origin' of people who organize and partake in protest, how they come together, and the circumstance that compel them to take part in protest have received little attention in political behaviour 
scholarship. In order to fill this lacuna, this paper explores the behaviour of agitators Fela and Gani through their socialization and class backgrounds.

\section{Utilizing the Social learning Theory}

The issue under study conforms to the basic assumptions of the social learning theory, especially as propounded by Albert Bandura. The social learning theory tries to provide explanation for individual's behaviour in relation to his socializing environments. The theory posits that individuals learn not just what they know, but also what they do, from other individuals in the society, rather than from their mental initiatives. According to Bandura, Learning will be exceedingly laborious, not to mention hazardous, if people had to rely solely on the efforts of their own actions to inform them what to do". He further asserts that "from observing others one forms an idea of how new behaviors are performed, and, on later occasion, this coded information serves as a guide for action (Bandura, Pp.19). Though often used in psychology, Bandura's social learning theory is capable of explaining many patterns of behaviour: political, social and otherwise, as if resting on Anderson's claim that " $A$ principal reason for the emphasis upon political behaviour research is the use which can be made of theories, concepts and techniques developed from other fields of social science" (I). The social learning theory therefore has an interdisciplinary explanatory capacity in the area of behaviour, and this extends to the political. The social learning theory is anchored on the following five basic assumptions.

- First, that the individual's mind remains a tabula rasa when he is born, until he or she gets to the society where some agents of socialization will model and condition it. 
- Second, that the individual begins his learning process through trial and error, where his activities are rewarded, resisted or ignored. Activities rewarded are positively reinforced while those ignored or resisted are negatively reinforced.

- Third, the individual's retention or otherwise of behaviour is based on primary reinforcers such as gifts, usually at childhood, and praise, from adolescence upward. So, by the time a child has developed into adulthood, he would have been fully molded into a particular mode of behaviour.

- Fourth, an individual positively reinforces the behaviors that attract praise and attention to him while he desists from activities that can withdraw the praises and attention. The individual continues with behaviour that attracts rewards even when there is danger, and with the fear of losing his praises and attention, he keeps on, even to the extent of getting to contradictions.

- Fifth, learning follows the principles of reciprocal determinism, and it is a causal relationship between the individual and the society where the society learns from the individual, the very things the individual learns from it. This is a radical departure from the one-way claim of behaviorism which states that only man learns from the society and not the other way round. The principle of reciprocal determinism also implies that so long as man exists within and interacts with others in the society, he or she continues to learn new things that will influence his behaviour even as others learn from him too. 
In line with the above principles, Gani and Fela's minds, as babies, and like any other ones, were quite open as tabula raza, until they began to gather consciousness from the behaviour, attitudes, actions and inactions of their family as agent of socialization. This created imitative and protest potentiality in the two of them as Niemi (1973) asserts that "political ideas, like consumption of cigarette and hard liquor, do not just begin at one's eighteen birthday...for in their political habit as consumption habit, young people are influenced by their parents and other family members and their school" (pp. II7).

\section{Explaining Gani Fawehinmi and Fela Anikulapo Kuti}

In providing theoretical explanations to the contentious political behaviour of two prominent Nigerian activists: Gani Fawehinmi and Fela Anikulapo Kuti, in terms of what factors made them the political agitators that they were, there is need to systematically examine and analyze their socialization and class, because, as Mabinuori (2003) observes, "in order to judge a man correctly, one must have a deep knowledge of the man"(pp. 6). To use Freeman's rather elegant language, "From where do they come" (1999:704), people like Fela and Gani, who were able to confront the venal, mercenary and ill-tempered post-civil war Nigerian military between 1970 and 1997? Under what family circumstances were they born and socialized? What forms of education and international exposure did they receive? Who did they peer-group with, and what were the day to day situations, encounters as well as incidents that marked their upbringing? How do answers to these questions combine to explain Gani and Fela's political personalities in Nigeria's socio political milieu? The life history approach will be used. 
As an approach, life history "is a deliberate attempt to define the growth of a person in a cultural milieu, and to make theoretical sense of it" (Dollard, cited in Labinjoh 1982: 120). This approach focuses on understanding the individual as a prelude to understanding the society, and it promises to assist the current paper in grasping a huge understanding of the political protest and agitation of Gani Fawehinmi and Fela Anikulapo Kuti of Nigeria.

\section{Who was Gani?}

Gani Fawehinmi was born on 22 April 1938 to a man called Chief Saheed Togunbo Fawehinmi, the Sarkin Musulumina of Ondo, and a successful timber trader, civil activist and great philanthropist. Gani's father was acclaimed to have brought Islamic religion to Ondo town, which was predominantly a Christian community in the South Western part of Nigeria. Gani's grandfather was the Late Chief Lisa Alujanu Fawehinmi of Ondo, a man who engaged in several successful battles for and on behalf of the Ondo people in the nineteenth century. He was fond of fighting for the oppressed in the Ondo society, and it was difficult for anyone to oppress another wherever he was, because, like a spirit that his name 'Alujanu' means in Yoruba- Hausa expression, no one knew when and how he would react to such oppression.

Gani had both his primary and secondary education in Ondo, and passed his West African School Certificate Examination in 1958 before he proceeded to London to train as a lawyer in Holborn College of Law, 196I. "While in college, he was popularly known as 'The Nation' because of his passionate interest in national, legal and political affairs". (Ugwozor pp. 69). Until his death in Nigeria in 2010, Gani Fawehinmi was reputed as the greatest agitator against, and antagonist of dictatorial and anti-people policies in Nigeria, and his protest and antagonism took the pattern of rallies and 
lawsuits. As at the age of 64, Gani had about 27 lawsuits against the government of Nigeria, most of the suits agitating for freedom and good life for Nigerian citizens. In pursuance of his goal and as a result of his protest and agitation against Nigerian government, especially the military, Gani was arrested and imprisoned for more than 35 times in his life time. Apart from this, he also suffered personal assault, property confiscation seizure of international passport and confiscation of book on countless occasions. "In a country where it is the conventional wisdom for people to mind their businesses, many wondered why Gani paid so much attention to others' businesses, and even when governments tried to persuade him to soft-pedal "2. Gani never did.

Nigerian and international observers have their comments about Gani Fawehinmi before he died. According to Dan Agbese, "Fawehinmi is tough; Fawehinmi is courageous. He has the toughness of personal conviction, and he has the courage to speak his mind......the greatest and the most erudite enemy of cant and hypocrisy this nation had ever had..." (Newswatch Magazine, April 29, 1985). In fact. General Ibraheem Babangida, one of the military dictators that Gani agitated and protested against also wrote about him that "If there is a man I respect, it is Gani, ... I appreciate him that he has a strong conviction and fight for it ruggedly" (Tell Magazine, July 1995). Gani is known locally for his rugged agitation against certain negative public issues that Ugwuzer ( 2002) calls "no one's business". The international community thinks in a similar way. An array of actors in international politics, including but not limited to $\mathrm{Dr}$ Walter Carrington of the United States, have paid homage to Gani. In fact, Joseph Contreras declared in the Newsweek magazine of October 10 th 1994, that " Gani is Nigeria's best known human rights attorney. $\mathrm{He}$ is also a leader of pro democracy movement that is currently protesting the de 
facto state of emergency imposed by the military regime of General Sanni Abacha" (Cited in Ugwuzor pp. I8I-182).

Although Fela was born in 1938 and he schooled both in Nigeria and Britain , it was in 1970 when he returned from a United States tour that he became politically conscious, and from that period till 1997 when he died, he strongly agitated and protested against policies of the Nigerian military government, using his songs and deviant behaviour (Olaniyan 2003; Eesuola 2012). Fela between 1970 and 1997 was 'agitation personified'. His was a 27 years of no agreement, as corroborated in the following answer he provided to a journalist who wanted to know his greatest achievement in his life:

The day I carried my mother's coffin to Dodan Barracks (in protest), my brother, on the 30th September 1979, people of this country didn't know what I faced on that day to do that... but, men, I had to do it... you see, they gave order to destroy the coffin that was placed in my house when I was in Berlin and I promised I must put it there. I knew I would succeed in getting it there but it was a big row...they wanted to shoot me and all that, but I came out of it. That is my greatest achievement in life (Cited in Eesuola 2012:3).

To Fela, the greatest achievement in the life of a man is the protest march he organized! His agitation was multidimensional: he created the Afrobeat genre of popular music with an unusual style of "politically charged lyrics and antiestablishment politics," through which he periodically "launched comprehensive venomous critique of both 
institutions and individuals he considered as causes and perpetrators of Nigeria's reigning incredible anomie" (Olaniyan 4). He started and sustained a social movement, albeit episodic: the Young African Pioneers, and he formed a political association, the Movement of the People (MOP), as a platform for contesting in the Nigerian general elections of 1979. Fela also made an attempt to create his own state: the Kalakuta Republic, in protest against the Nigerian state. Fela exhibited series of countercultural and iconoclastic behaviour to attack the dominant order in Nigeria. As a musician, his songs in many cases confrontationally addressed and protested against socio political problems in Nigeria and Africa, and the songs hit so hard that successive Nigerian governments, especially of the military interregnum, labeled most of them NTDB, that is, Not To Be Broadcast. Apart from songs, Fela also indulged in different deviant behaviors as forms of protest against the dominant political order until 1997. So, unlike many musicians in his generation who either indulged in "the illusory notion of arts for arts' sake" (Ayu, pp. 3), or who simply sing- praised the ruling class to reinforce their incredible anomie, Fela's life and career metamorphosed into serious agitation and protest against the Nigerian establishment; and in such a way that had not been witnessed in the social sciences and humanities.

Till date, majority of the socio-political issues Fela agitated and protested against remain relevant in the politics and governance of Nigeria, Africa and the entire world. This suggests why Olaniyan declared in reference to Fela's songs, writings and actions, that "it is rare that the work of a popular musician intervene so cogently in current dominant problematics in the social sciences and humanities" (pp. 4). Corroborating Olaniyan's foregoing assertion are the following words of a foremost Fela- influenced musician, Lagbaja, in a tribute to Fela his mentor: 
When he starts to yap

Dictators go dey shake Oppressors go dey fear When he put mouth for song Philosophy go de flow
When he starts to banter

Dictators shudder in alarm Oppressors quake in fear When he begins to sing Philosophy issues forth... (Olaniyan, pp. 6)

Using such socio political concepts as "dictator" and "oppressor" to describe the targets of Fela's lyrical agitation, and describing Fela's utterances as essentially philosophical, Lagbaja merely prompts a host of scholars who have explored Fela in several dimensions, asserting several issues such as his ingenious and unique creation of the political genre of popular music called Afrobeat (Oikelome, 2009), his political philosophy no agreement (Olaniyan, 2004), Fela as a 'moral reformer' (Olaniyan, 2004), a cultural nationalist (Olorunyomi, 2003), a protest musician (Ayu 1986), and, to mention just a few, a socio-.political soothsayer who constantly saw the political tomorrow of Nigeria and indeed Africa (Mabinuori. 2003).

\section{Summary and Conclusion}

Narrowing down my interest to political agitators, I introduced this paper by asserting that political behavior needs to focus more on people and how they become the political personalities that they are, because doing this will not only fulfill the main thrusts of the behavioral aspiration in political science, but also help us explain certain developments in the social-political behaviour of people around the globe. This is followed by exploration of literature on political agitators: different reasons that explain their agitation really. Exploration of literature reveals that scholars have explained agitation and protest as the reaction of men towards the socio-political contradictions amongst them, but 
are silent on people who have peculiar personalities that dispose them to protest and agitation, especially based on their socialization and class. I used the social learning theory, especially of Albert Bandura as explanatory framework, for the cases of the two research eponymy, Gani Fawehinmi and Fela Anikulapo Kuti, and using the life history approach too.

Two major things then become clear: One, both Gani and Fela were born into, and socialized by families of radical fathers. As described in the foregoing life histories, Gani's father, Chief Saheed Tugbobo Fawehinmi, the Sarkin Musulumina of Ondo, was a civil activist and great philanthropist who fought for many Ondo people on an array of issues. As a matter of interpretation, it took a radical personality, an activist and an agitator of some sort to bring Islamic religion to a predominantly Christian community like Ondo, the way Gani Fawehinmi's father did, because such an action would have been done through much agitation and protest, and in deviance of the dominant order at this time.

Fela's father was, on the other hand, not too different from such an anti establishment person. According to Mabinuori (1986), Fela's father, Canon I. O Ransome Kuti, who "wanted to be a lawyer," refused to preach in church throughout his clergy career because his own father had forced him to be a Reverend. As a form of protest against this, Fela's father abandoned the pulpit and took to politics of the left, so, according to Mabinuori (I8), he became "a voice in the Nigerian political arena. ...and was also the first president of Nigerian Union of Teachers" Mabinuori asserts further that "as the principal of Abeokuta Grammar School, he (Fela's father) never allowed any white inspector to inspect his school. The one who tried to, he flogged out of his school because he had insisted upon inspection after Rev Kuti had objected to it". In another instance, this time a dramatic one, 
$\mathrm{He}$ (Fela's father) was passing through the premises of the military cantonment in Abeokuta with his cap on, when a soldier instructed him to remove his hat as he walked past the British flag. Rev I.O Kuti refused to obey the orders and the soldiers tried to force the hat out of his head with a bayonet... Daudu almost lost an eye from injury sustained from this barbaric act of Nigerian colonial soldiers....he protested bitterly to the authorities and, in the end, the soldiers barracks had to be removed from the heart of the town where this incident occurred, to the then outskirt of the town in Lafenwa (Mabinuori, pp. 18).

While Mabinuori concentrated on Fela's father's influence on his socialization, other authors gave maternal dimension to it. In fact, most of the authors posit that Fela's greater influence came from his mother, Mrs. Olufunmilayo Ransome Kuti, who later changed her name to Funmilayo Anikulapo Kuti, in support of his son's protest philosophy that Ransome was a slave name, and that whoever was called by it was suffering from 'colonial mentality' Labinjoh (1982) described Fela's mother as a prominent member of the National Congress ${ }^{\wedge}$ of Nigerian Citizens (NCNC) who led several anti-colonial and taxation protest against the British. $\mathrm{He}$ claimed that these activities were there for Fela to see and emulate, and that it was not surprising that Fela began to experiment his own method of fighting the establishment when he returned from the United States in the 1970s. Another author, Shonekan, writes that "Fela's experience with activism began with his study of his mother's political movements. As a child born in 1938, he observed her 
activities and became the most radical of her four children. His foundation had been firmly set by the time he left home for studies abroad" (2009:5).

To conclude therefore, if indeed the duo of Gani Fawehinmi and Fela Anikulapo Kuti were socialized under the kind of family traditions highlighted above, it is very likely that through observations, imitations, reinforcement and reciprocal determinism, their personalities were exposed to protest, agitation, countercultural and anti- establishment behaviour during their socialization in the family. Both Gani and Fela also schooled in London, around the same time, and, given their further exposure to alternative political environments in the course of their continuous socialization abroad, they would have been able to compare and contrast governments and then derive such value judgment that would make them discriminate and agitate against certain ones at home in Nigeria. This is in line with what the Social Policy Centre means by writing that "the agitator is one who exaggerates the difference between one rather desirable policy and another". People who are exposed to alternative political systems are more likely to become agitators in their own political systems.

Fela's political protest and agitation were also significantly influenced by his travel to the United States in 1969. In fact, many scholars have concluded that apart from the formal education he had in Abeokuta Grammar school, Nigeria, and Trinity College of Music, London, Fela received a great deal of informal education and situated learning in the United States. So, for Fela and Gani alike, socialization at the levels of the family, tertiary institution and alternative poetical environment contributed to their becoming agitators.

The political environment in which the two agitators lived and socialized also contributed to the formation of their contentious personalities. As Gani took the military to court 
on more than twenty occasions challenging one policy or the other, Fela Kuti also composed many songs such as Zombie (1976) ITT (1979) AS (1980) CCM (1989) and GOC (1990), all which contained venomous anti- military and antigovernment lyrics. He also gave several public lecture and organized protests. Put together again the political environment in which Gani and Fela socialized could not have built them into such political personalities that they eventually became.

As Labinjoh observes that "socio economic circumstances always constrain members of various classes to relate differentially lo the social structure", the middle class to which Gani and Fela belonged also informed their disposition to political issues. Gani's father was a successful timber merchant while Fela's was a reverend and school principal both of whom could afford to sponsor their children for university education in the United Kingdom, at a time when only the financially privileged could do so. In other words, both Gani and Fela were not, at birth and latter in life, preoccupied with material deprivation, and they had enough time and resources to invest on the very risky and expensive behaviour of political agitation, especially in a post civil war military interregnum Nigeria. The implication here is that so long as the society will often have the middle class, and the middle class will often likely produce political agitators who will in turn produce others through socialization, every political society will always produce political agitators. What may be learnt from this is that the governments of the developing countries especially should come to terms with the inevitability of political agitators in their polities, and they should deal with them on the merits of the issues they agitate against.

Agitation serves a lot of positive purposes in the socio- political development of a country, and the purposes 
cut across classes and stratifications. While "in most cases it is an attempt at influencing the politics and policies of government ... in order to increase the responsiveness of government to their needs and demands" (Adole, Pp. II), the political class and government also benefit from it because it can serve as "strategic tools in domestic power struggle...to gauge and communicate their relative influence" (lyengar, pp. I). Political agitation also serves as a way of preventing violent behaviour such as terrorism and riot, since, again according to lyengar, "it provides an outlet for the release of frustration and anger, and it can also contribute to political education by stimulating the acquisition of political attitudes and values".

In the light of the above benefits, and in the face of the inevitability of agitations and agitators in any political organization, governments of developing countries should, rather than repress and suppress agitators, utilize the opportunity offered by their critical thinking to enhance the development of the polities. Fela says " if someone is not firm, the society will break up" (Hoskyns, 1984), and the implication here is that every society, however full of contradictions, will in most cases produce some semblances of firm personalities who will agitate and protest against the status quo. Such personalities are the conscience of that society, and rather than being repressed and oppressed, they deserve to be heard and protected on critical platforms.

Olukayode Segun Eesuola Department of Political Science and International Relations North West University, Mafikeng, South Africa 


\section{REFERENCES}

Ake, C. (198). A political economy of Africa. London: Longman, I98I.

Anderson, C. (2007). The interaction structures and voters' behaviors. In, Dalton, R. and Klingemann, H. (eds.), The Oxford Handbook of Political Behaviour. Oxford: Oxford.

Anifowose, R. (1982). Violence and politics in Nigeria. New York: NOK.

Auvinen, J. (1997). IMF Intervention and political protest in the Third World: A conventional wisdom refined. Third World Quarterly, 17(3), 337-400.

Ayu, I. (1986). Creativity and protest in popular culture: The political protest in the popular music of Fela Anikulapo Kuti. In, Essays in popular struggle. Nigeria: Pan African Publishers.

Bandura, A. (1973). Aggression: A social learning analysis. New Jersey: Prentice Hall.

Charles, A. (1996). Political movement and social change: Analyzing politics. American Political Science Review, 90(4), 874-884.

Conway, M. (1989). The political context of political behaviour. Journal of Politics, 5I(I), University of Texas Press.

Dalton, R. (2002). Citizens' politics, public opinion and political parties in advanced industrial democracies. UK: Chatman House.

Dalton, R. \& Alix, V. (2004). Why people protest? The resource, structural and cultural bases of protest. 
Paper presented at the annual meeting of the American Political Science Association, Chicago III.

Derrick, J. (1988). African agitators: Militant anti colonialism in Africa and the West, 1918-1913. London: Hurst and Company.

Davies, J. (1962). Towards a theory of revolution. American Sociological Review, 27, (I), 5-19.

Easton, D. (1965). A system analysis of political life. New York: Willey.

Eisinger, P. ( 1973). "The condition of protest behaviour in American cities. American Political Science Review, 67, II-28.

Ekeh, Peter. (1975). Colonialism and the Two Publics in Africa: A theoretical statement. Comparative Studies in Social History,: 17, 91 -I I2. 1975. Print.

Eldersveld, J. \& Katz, D. (I96I). The impact of local party activities upon electorates. Public Opinion Quarterly, 25(I), I-24.

Freeman, J. (1999). On the origin of social movement. In, Social movement of the sixties and seventies: American Journal of Sociology : 78(4), 702-8II.

Gostin, L. (1988). (ed). Civil liberties in conflict. London and New York. Rutledge.

Gurr, Ted. (1970). Why men rebel. Princeton: Princeton, University, 1970.

Herring, C. (1989). Acquiescence or activism? Political behaviour among the politically alienated. Political Psychology, I0(I), I35-153. 
Holier, E. (I95I). The true believer. New York: Harper and Row.

Hollander, J. and Einwohner, R. (2004). Conceptualizing resistance: Sociological Forum, 19(4), 533-554.

Hoskyns, B. (1984). Fela Kuti: He who has a quiver in his underpants. Interview, NME.

Ihonvbere, J. (1996). A radical view of Nigeria's political development. In, Oyediran, O. (Ed.), Governance and development in Nigeria, essays in honor of Professor Billy $\mathrm{J}$. Dudley. Ibadan: Oyediran.

Lyengar, S. (1977). Political agitation and childhood political learning: The case of Andhra Pradesh. The Journal of Developing Areas: 12 (3-16). October 1977.

Jasper, J. (1998). The emotions of protest: The affective and reactive emotions in and around social movements. Sociological Forum, I3, (3), 397-424.

Joseph, R. (1991). Democracy and prebendal politics in Nigeria: The rise and fall of the Second Republic. Ibadan: Cambridge University.

Kaplan, H. \& Xiaoru, L.( 2000). Social protest and self enhancement: A conditional Relationship. Sociological Forum, I5(4), 432- 442.

Klapp, O. (1969). Collective search for identity. New York: Holt, Rinehart and Winston.

Labinjoh, J. (1982). Fela Anikulapo Kuti: Protest music and social processes in Nigeria. Journal of Black Studies. 13 (I) Communication and Change in Sub Sahara Africa, II9-134.

Lipset, S. (197I). Rebellion in the university. Boston: Little Brown. 
Mabinuori, K. I (1986) Fela: Why black man carry shit. Ikeja: Opinion.

Mabinuori, K. I. (2003). African who sang and saw tomorrow. In, Schoonmaker, T. (Ed), Fela: From West Africa to West Broadway. New York: Palgrave Macmillan, 16-24.

McAdam, D. (1986). Recruitment to high risk activism: The case of freedom journal. American Journal of Sociology: 92,64-90.

McAdam, D. (1982). Political process and development of black insurgency, 1930 - 1970. Chicago: University of Chicago Press.

McAdam, D., Tarrow, S., \& Tilly, C. (200I ). Dynamics of contention. Cambridge: Cambridge University Press.

Moore, C. (1982) Fela: Fela this bitch of a life. London: Alison and Busby.

Niemi, R. (1973). Collecting information about the family: A problem in survey methodology. In Denis, J. (1973). Socialization to politics. New York: John Willy and Co.

Obeschall, A. (1973). Social conflicts and social movement. New Jersey: Prentice Hall.

O'Connor, J. (1973). The fiscal crisis of the state. New York: St. Martins.

Olafsson, J. (2007). Deviance: A comment on the logic of protest: TRAMES, II, (6I), 432-442.

Olson, M. (1963). Rapid growth as a destabilizing force. Journal of Economic History (23) 529-552.

Olaniyan, T. (2004). Arrest the music! Fela and his rebel arts and politics. USA: Indiana University. 2004. 
Olorunyomi, S. (2003). Afrobeat: Fela and the imagined continent. Ibadan: IFRA.

Opp, K. D. (2009). Theories of political protest and social movement: A multi-disciplinary introduction, critique and synthesis. New York: Rutledge, 2009. Print.

Parson, T. (1963). Some reflections on the place of force in social process. In, Harry, E.(ed). International war: Problems and approaches. New York: Free.

Passy, F. (200I). Socialization, connection and the structure agency gap: A specialization on the impact of network on participation in social movement mobilization. International Journal, 6(2) I73-192.

Peterson, S. (1990). Political behaviour: Patterns in everyday life. London: Sage.

Putnam, R. (2000). Bowling alone: The collapse and revival of American community. USA: Touchstone.

Robinson, K. (2003). The father, the son and the holy ghost. In, Schoonmaker, T. (ed) Fela: from West Africa to West Broadway. New York: Palgrave Macmillan, I0-I5.

Rose, R. (2007). Perspectives in political behaviour in time and space. In, Dalton and Klingeman (2007), (eds.). Handbook of political behaviour: 282-30I.

Schoonmaker, T. (ed) Fela: From West Africa to West Broadway. New York: Palgrave, 2003. Print.

Shonekan, S.(2009). Fela's foundation: Examining the revolutionary songs of Funmilayo Ransome Kuti and the Abeokuta Women's Movement in 1940s Western Nigeria. Chicago: Centre for Black Research. 2009. 
Schussman, A. \& Soule, S. (2005). Process and protest: Accounting for individual's protest participation. Social Forces, 84, (2), 1083-II 08.

Soyinka, W. (2006). You must set forth at dawn. Ibadan: Book Craft.

Tarrow, M.\& Tilly, C. (200I). Dynamics of contention. Cambridge: Cambridge University Press.

Turner, R. (1969). The theme of contemporary social movement. British Journal of Sociology, 10, 390-405.

Ugwuzor, A. (2002). A glance at Gani at 64. Lagos: Nigerian Law Publications Limited.

Useem, B. \& Useem. M. (20010. Government legitimacy and political stability. Social Forces. 3,57, $840-852$.

Veal, M. (2000). Fela: The life and times of an African musical icon. Philadelphia: University.

Verba, S., Schussman, K., \& Henry, B. (1995). Voice of equality, civil voluntarism in American politics. USA: Harvard University Press.

Verba, S., Schussman, K., \& Henry, B. (1995). Voice of equality, civil voluntarism in American politics. USA: Harvard University Press.

Verba S., Donald, J., \& K-Lehman, S. (1997). Knowing and caring about politics, gender and Political engagement. The Journal of Politics, 59, (4), I05I-1072.

Zurcher, L. \& David, S. (198I). Collective behaviour, social movements in Social Psychology. In Rosenberg, M. \& Turner, R. (Eds.). London: Basic books. 